\title{
Enhancing Apparel Store Patronage through Retailers' Attributes and Sustainability. A Generational Approach
}

\author{
Dan-Cristian Dabija *(1) and Raluca Băbut \\ Department of Marketing, Faculty of Economics and Business Administration, Babeș-Bolyai University, \\ 400591 Cluj-Napoca, Romania \\ * Correspondence: cristian.dabija@econ.ubbcluj.ro
}

Received: 16 July 2019; Accepted: 19 August 2019; Published: 21 August 2019

\begin{abstract}
While research on retailers' attributes that influence store patronage is relatively plentiful, the influence on store patronage of consumers' perceptions towards retailers' sustainable behaviour is a new topic. The authors examine the influence of retailers' sustainable behaviour and store attributes (assortment, price, personnel, advertising and convenience) on the patronage behaviour of generations X and Y (Millennials). Data were collected via a survey of 278 Xers and 402 Millennials in an emerging market. Results show that Generation $X$ apparel store patronage is positively influenced by advertising and store personnel, whereas Millennials' are influenced by assortment, personnel and advertising and to a weaker extent by retailers' sustainable behaviour. The paper enlarges the understanding of generational theory in an emerging market, while from a managerial perspective the results are particularly useful for apparel retailers with regards to marketing strategies which need to be implemented in order to attract and retain Generation $X$ and $Y$ consumers.
\end{abstract}

Keywords: apparel retail; sustainability; store attributes; store patronage; Millennials; Xers

\section{Introduction}

The importance of sustainability is increasing in apparel retail due to customers' concern for respecting social responsibility practices, adopting environmental protection norms and ensuring proper working conditions [1-5]. As consumers are direct end-users of clothes, their assessment of apparel retailers' social responsibility practices is much more intensely perceived than in the case of other products [6]. Therefore, apparel retailers are compelled to develop their business in a sustainable manner in order to generate competitive advantage and develop loyal behaviour [7-9].

Faced with fierce market competition, new customer expectations and the need to implement a sustainability strategy, apparel retailers must understand the factors that influence store patronage behaviour to ensure a loyal customer base. Long-term success is corellated with understanding patronage behaviour, which becomes a major objective of retailers [10].

Retailers' attributes which exert an influence on store patronage have been intensively studied [9,11-14], but no study has taken into consideration the influence of consumer perceptions towards retailers' sustainable behaviour on store patronage. This approach is relevant, as the importance and role of sustainability for the current apparel market is not studied to wide $[15,16]$. Thus, the purpose of this study is to develop and test a model that measures the influences exerted by sustainability, store personnel, ambiance, communication, prices, convenience and assortment on store patronage. The study was conducted in an emerging market (Romania) with a fast-growing potential.

Our research is based on Generational Theory. A Generation is defined as "a cohort-group whose length approximates the span of a phase of life and whose boundaries are fixed by peer personality" [17]. Being born during the same period and being exposed to the same macro-level social, political and economic events during their coming-of age years, generational cohorts share 
similar attitudes about family life, gender issues, institutions, religion, politics, lifestyle and the future $[17,18]$, which significantly influence their purchasing and consumption behaviour $[19,20]$. Diverse life experiences allow generations to differ one from another regarding lifestyle, expectations, values and behaviour [21]. Due to globalization and technology development, which has allowed increased access to information, the generational cohorts from different countries share more similarities now than in the past $[18,19]$. From a marketing perspective, Generational Theory facilitates market segmentation [13,18,20] and the developing of more effective marketing strategies [21].

The aim of this paper is to highlight the patronage behaviour of two consumer generations-Xers and Millennials (Generation Y)-towards apparel stores. Previous research has suggested that differences between Xers and Millennials in an emerging market might be stronger than those between Baby Boomers and Xers or Millennials and Generation Z [22]. While Millennials have grown up with digital media and online technologies [23-25] being oriented towards green products and sustainability [20,26], Xers learned these realities at their maturity [27]. The analysis of different consumer generations, especially Baby Boomers, Xers and/or Millennials has already been the focus of some literature [28-31], but to date no authors have considered apparel retail patronage.

The remainder of this paper is organized into four major sections. First, we review the concept of store patronage and its determinants and develop the research hypothesis. Second, we describe the research context and methodology of the empirical study. We then present and discuss the results of our research. Finally, we highlight the theoretical and managerial implications, as well as future avenues of research that might be conducted based on these results.

\section{Literature Review: Retail Store Patronage and Its Determinants}

The retail patronage behaviour concept includes the likelihood of buying at the store, revisiting the store and recommending it to others [11,12,14,32]. Zeithaml [33] proposed that value perceptions, which influence consumer purchasing decisions, are based on perceptions of product quality (what consumers get) and price (the monetary and non-monetary aspects). Baker et al. [11] proposed a model in which store environmental dimensions (social, design, ambient factors) influence consumer perceptions of store choice criteria (interpersonal service quality, merchandise quality, monetary price, time/effort cost and psychic cost) which affect store patronage intentions. Chang et al. [14] tested a model in which store attributes (product-related, service quality-related, and store-related attributes) are significantly related to consumer satisfaction, which in turn influences retail patronage behaviour. To identify the antecedents of retail patronage, Pan and Zinkhan [12] conducted a meta-analysis, showing that retail patronage is determined by assortment and quality of merchandise, services, store atmosphere, low price level, fast check-out, shop opening hours, friendliness of store personnel, parking facilities and store convenience. Sustainability emerges as a new dimension that enables the enhancement of retail store patronage $[4,5,34,35]$.

Sustainable development. Finding solutions to environmental problems caused by excessive pollution is a challenge for both businesses and consumers around the world [36-38]. On the one hand, companies are favour sustainable practices in order to obtain competitive advantages in markets characterized by increasing regulatory levels, reduction of resources, climate change and social pressures $[39,40]$. On the other hand, consumers, especially the younger generation, understand that they need to change their attitudes and behaviours [41,42].

Although there are many definitions of sustainable development, the most commonly used is that proposed by the World Commission on Environment and Development [43]: "The development that meets the needs of the present without compromising the ability of future generations to meet their own needs". From a holistic perspective, sustainable development relies on a business finding market opportunities which allow it to generate competitive advantage by combining economic, social and environmental dimensions into a harmonious and synergetic action [44-46]. Companies' sustainable strategies should be aimed at gaining profit by showing respect for the planet's limited resources, for 
people in general and for their own employees, as well as for the community and partners within the supply chain [47-49].

Nowadays, manufacturers and retailers are eager to pursue sustainable goals, as consumers are well informed about the conditions under which products are made and distributed [50] and expect retailers to offer products and services manufactured according to social and environmental principles [9]. Consumer perceptions of companies' social responsibility affect both their image and financial performance $[8,51]$. Moreover, the consumer perceived ethicality of the retailer influences retail patronage [52]. Therefore, we hypothesize that:

Hypothesis 1. Consumer perceptions of retailer's sustainable behaviour have a direct influence on apparel store patronage.

Assortment/Merchandise. Consumers' interest in merchandise to suit their needs and desires [53] helps retailers to gain competitive advantage by adapting their assortment strategy accordingly. This can generate customer loyalty and ensure a retailer's financial success [54]. Consumers are also encouraged to revisit stores which offer an innovative, wide assortment of goods [55], change their store layout and offer trendy products [56]. The variety and quality of merchandise has an overwhelming effect on how individuals choose the apparel store where they intend to shop in the future [55-59]. Therefore, we argue that:

Hypothesis 2. Consumer perceptions of retailer's assortment (merchandise) directly influence retail store patronage.

Prices. Prices and the quality/price ratio generate competitive advantage for retailers. Fair prices are deeply ingrained in customers' minds [60], as consumers often associate high price with high quality [61]. Price is one of the factors influencing store choice and patronage behaviour $[62,63]$. For apparel stores, price is hence an important attribute affecting store choice $[59,64]$. Therefore, we infer that:

Hypothesis 3. Consumer perceptions of retailer's prices have a direct impact on apparel store patronage.

Atmospherics. Atmospherics improves the store's spatial aesthetics and represents the subtle and silent language influencing customers at cognitive, affective and behavioural level [65]. Store atmospherics and ambiance characteristics (lighting, temperature, spaciousness, layout, cleanliness, etc.) are factors significantly affecting store choice [54], while store atmospherics offering a positive experience increases retail patronage [66,67]. Store design influences consumers' preferences and price perception, and the quality of services and sold products, enhancing the shopping experience $[11,56]$. Based on these aspects, we consider that:

Hypothesis 4. Consumer perceptions of retailer's atmospherics directly influence apparel store patronage.

Store personnel. Retailers rely on qualified, skilled and friendly personnel to attract and retain customers $[12,57,65,68]$. As many retailers rely on both an offline and online presence, and adopt a multi-channel approach, in order to achieve a proper differentiation through distribution channels and to boost their sales, they rely on competent and polite sales personnel, who are able to give proper advice and improve customers' shopping experience [69]. Politeness, knowledge of merchandise and willingness to help may influence patronage behaviour [70,71]. Research on apparel stores [57,58,72,73] reveals that friendly, polite, attentive, skilled personnel willing to provide help and information is an important factor in attracting and gaining the loyalty of customers. Therefore, we argue that:

Hypothesis 5. Consumer perceptions of retailer's sales personnel impact apparel store patronage. 
Advertising. Advertising is the major means of communication for attracting consumers to stores and promoting retailers' brands, assortments and new offers [74,75]. Consumers are exposed to an increasing number of advertisements, as retailers strive not only to gain competitive advantages, but also to help clients to become informed when making buying decisions [54]. Advertisements attract consumers' attention, increase retailer awareness [56] and significantly influence consumer preference for a store [76]. Therefore, we infer that:

Hypothesis 6. Consumer perceptions of retailer's advertising have a direct influence on apparel store patronage.

Convenience. Customers are unlikely to visit a store unless it is accessible both spatially and temporally: being in proximity to home or work, offering parking facilities, being connected to the road and public transportation infrastructure are key elements for attracting customers [77]. As consumers allot less time for shopping offline, and as the advancement of e-commerce is underway, convenience can allow retailers to differentiate from the competition [61]. Distance to stores, walking and/or driving time to stores and ease of transportation all influence consumer decisions to visit a store $[56,78]$ and to remain loyal [71]. Based on this, we believe that:

Hypothesis 7. Consumer perceptions of retailer's convenience impact apparel store patronage.

\section{Research Methodology}

\subsection{Research Context}

We decided to focus on an emerging European economy, Romania, through the lens of the generational theory, as Romania has one of the most booming economies among recent entrants into the European Union [79]. As in the first years after the 1989 Romanian Revolution, when many international grocery retail chains penetrated the market, since 2000, more and more fashion and apparel retailers have begun to open stores in the main cities, mostly in shopping malls [80]. Clothing and footwear specialized stores represent the most important distribution channel in the apparel market, with a 58.4\% share of sales in 2015 [81]. The main competitors are hyper- and supermarkets, which carry cheap but fashionable clothing and footwear [82]. However, the market is still dominated by domestic retailers who focus mostly on price-sensitive consumer segments, independent stores being found even in the remotest, least developed rural areas, carrying cheap, no-name or counterfeit products [83].

As mentioned earlier, this study focuses on two generational cohorts: Xers and Gen Y (Millennials). Generation X consists of individuals born between 1961/1965 and 1977/1980 [23,29,84,85]. In emerging countries, Xers have grown up in an environment with shortages and poverty, having witnessed the fall of communism, and therefore developing a different cultural and social profile [27]. Xers are mainly pragmatic, flexible, individualistic and sceptical [86], but they are also multiculturally oriented and tend to think globally [87]. This generation is focused on the quick, intelligent and effective fulfilling of objectives, even if it means bending the rules [88]. As consumers, Xers like to inform themselves before taking buying decisions [30]. They often ignore advertisements and base their decisions on the opinions of peers, buying from value-oriented retailers [30,89]. Xers are more concerned about environmental issues than Baby Boomers [90], try to acquire healthy and/or organic foodstuff, and to use recyclable products, being mainly motivated by care for their children's health [27,91].

Millennials (Gen Y) are people born between 1980/1981 and 1994/1995 [23,84] or 1999/2000 [23,29, $92,93]$. Millennials have grown up in a time characterized by economic welfare, internationalisation of company activities, and the development of the Internet and social networks [20]. Openness towards communication, digital competences and presence on numerous social networks are some distinctive characteristics of Millennials [93,94]. They are oriented towards achieving personal goals in a short period of time, are confident, optimistic, multi-tasking, open and keen to have fun [93]. The development of retail and the increasing number of products and brands has led to the rise of a retail 
culture among Millennials, for whom shopping is a form of entertainment and socialization [94,95]. Having easy access to information, they often consult several information sources before taking a decision; they also shop more often and spend more money than Xers or Baby Boomers [96]. Millennials are brand conscious, being influenced by peers and celebrities when buying clothes [97], and by their personal experience of a retailer [20]. Eager to be independent, Millennials will patronize retailers that have attributes, products and brands that fit their personality or what they want to become [94,98]. Most Millennials are preoccupied with adopting environmentally friendly behaviour and are willing to pay higher prices for sustainable products and/or services $[99,100]$.

\subsection{Research Design}

A model was developed and empirically tested to explain the influence of retailer attributes (store personnel, atmospherics, advertising, prices, convenience, assortment, sustainable behaviour) on store patronage, as seen as in Figure 1. All constructs were measured on a five-point Likert scale (total disagreement/total agreement and were operationalised according to the literature, see in Table 2).

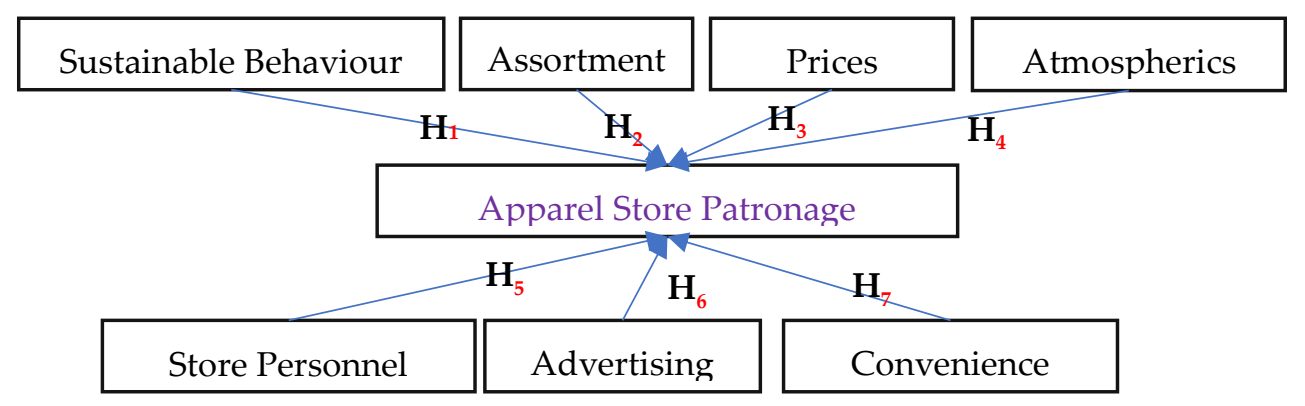

Figure 1. Research model.

Data was collected by means of face-to-face interviews with the help of volunteers supervised rigorously by the authors. Geographical and socio-demographic sample representativeness was ensured: respondents belonged to three development regions of Romania (out of eight). Volunteers selected respondents according to gender (male/female) and birth year, based on a quota sampling plan drawn up in compliance with the Statistical Yearbook [101]. The face-to-face interviews were carried out in public places, near stores or at respondents' homes. Respondents were asked to think about and name one single clothing store which they most often visited and to assess the sustainable behaviour, assortment, price, personnel, advertising and convenience of that retailer. 611 assessments $(90 \%)$ were made of stores belonging to international chains (Zara, Bershka, Stradivarius, New Yorker, C\&A, H\&M, etc.) and 69 assessments (10\%) were of domestic retailers (Bigotti, Guara, Effect, Eponje, IQ, DH Sport, etc.).

Respondents were later categorized according to their birth year into one of the two generations considered, according to literature recommendations [29,84,85,93]: Xers (born between 1965-1979) and Millennials (1980-1994). From 680 respondents, 278 (41\%) were Xers and 402 (59\%) were Millennials. There were $354(52 \%)$ women and $326(48 \%)$ men. 592 persons $(87 \%)$ lived in urban areas while 88 lived in rural ones (13\%). The sample was representative in terms of gender (male/female) according to the Statistical Yearbook [101]. 235 Xers and 327 Millennials had a third education degree, while 20 Xers and 98 Millennials had only graduated from high school.

\subsection{Data Analysis}

Collected data was checked for validity, reliability and internal consistency, as seen in Table 1 by means of Cronbach $\alpha(>0.7)$, "item-to-total" correlation, KMO criterion $(>0.7)$ and Bartlett's test of sphericity [102], through an exploratory factor analysis for each construct, see in Table 2. 
Table 1. Data testing.

\begin{tabular}{|c|c|c|c|c|c|c|}
\hline Dimension & Items & $\alpha^{1}>0.7$ & $\mathrm{KMO}^{2}>0.7$ & $\chi^{2} ; \mathrm{df} ; \mathrm{p}^{3}$ & Eigen-Value & $\%$ Variance \\
\hline Sustainability & 9 & 0.892 & 0.908 & $3966.85 ; 36 ; * * * *$ & 4.882 & 54.24 \\
\hline Assortment & 6 & 0.810 & 0.841 & $1586.56 ; 118 ; * * * *$ & 3.088 & 51.46 \\
\hline Store prices & 4 & 0.772 & 0.742 & $1030.62 ; 63 ; * * * *$ & 2.394 & 60.63 \\
\hline Atmospherics & 5 & 0.838 & 0.853 & $1664.55 ; 16 ; * * * *$ & 3.050 & 61.01 \\
\hline Store Personnel & 4 & 0.854 & 0.821 & $1573.99 ; 6 ;{ }^{* * * *}$ & 2.782 & 69.54 \\
\hline Advertising & 6 & 0.818 & 0.855 & $1637.23 ; 10 ; * * * *$ & 3.162 & 52.69 \\
\hline Convenience & 5 & 0.816 & 0.801 & $1521.60 ; 10 ; * * * *$ & 2.888 & 57.76 \\
\hline Retail/Store patronage & 6 & 0.841 & 0.860 & $1943.68 ; 15 ; * * *$ & 3.346 & 55.76 \\
\hline
\end{tabular}

${ }^{1}$ Cronbach $\alpha$ coefficient (data reliability). ${ }^{2}$ Kaiser-Meyer-Ohlin criterion for each dimension. ${ }^{3}$ Bartlett's test of sphericity $\left(\chi^{2}\right.$ : chi square; df: freedom degrees; $p$ : probability; $\left.{ }^{* * *} p<0.001\right)$.

All dimensions were included in a single exploratory factor analysis [103]. Based on the fit indices (KMO: $0.919>0.7, \chi^{2}: 16,148.815^{* * * *}$ df: 741 ) exceeding the minimum thresholds, the results confirm the extraction of eight factors, as seen as in Table $2[104,105]$.

Table 2. Factor analysis.

\begin{tabular}{|c|c|c|c|c|}
\hline Apparel Store X ... & Loading & Construct/Operationalisation & EV & $\%$ of var. \\
\hline$\ldots$ is responsible towards the environment. & 0.776 & \multirow{10}{*}{$\begin{array}{c}\text { Sustainability } \\
{[106,107]}\end{array}$} & \multirow{10}{*}{4.52} & \multirow{9}{*}{11.58} \\
\hline ... supports worthy causes. & 0.773 & & & \\
\hline$\ldots$ is concerned with improving society welfare. & 0.741 & & & \\
\hline ... keeps up high ethical standards. & 0.737 & & & \\
\hline$\ldots$ is concerned with environmental protection. & 0.731 & & & \\
\hline$\ldots$ is socially responsible. & 0.711 & & & \\
\hline ... forfeits profits to ensure a clean environment. & 0.627 & & & \\
\hline ... protects employees. & 0.623 & & & \\
\hline ... makes sustained efforts to create new jobs. & 0.538 & & & \\
\hline ... provides a pleasant shopping atmosphere. & 0.750 & & & \multirow{5}{*}{25.49} \\
\hline ... has good ambiance. & 0.716 & \multirow{4}{*}{$\begin{array}{c}\text { Store atmospherics } \\
{[108]}\end{array}$} & \multirow{4}{*}{9.94} & \\
\hline ... has a layout that helps me easily find products. & 0.696 & & & \\
\hline ... shopping is comfortable and simple. & 0.689 & & & \\
\hline$\ldots$ is always clean, neat and tidy. & 0.651 & & & \\
\hline$\ldots$ is in an easily accessible location. & 0.722 & \multirow{5}{*}{$\begin{array}{c}\text { Convenience } \\
{[68,109]}\end{array}$} & \multirow{5}{*}{2.16} & \multirow{5}{*}{5.55} \\
\hline$\ldots$ is in a good location. & 0.715 & & & \\
\hline$\ldots$ is in a perfect location. & 0.701 & & & \\
\hline$\ldots$ is in a location with similar stores. & 0.669 & & & \\
\hline$\ldots$ is in a good location (food, other stores etc.) & 0.634 & & & \\
\hline ... provides information about itself. & 0.735 & \multirow{8}{*}{$\begin{array}{l}\text { Advertising } \\
{[74,110]}\end{array}$} & \multirow{8}{*}{1.92} & \multirow{8}{*}{4.93} \\
\hline ... has appealing advertising. & 0.663 & & & \\
\hline ... has credible advertising. & 0.663 & & & \\
\hline ... has advertising that helps me plan my shopping. & 0.645 & & & \\
\hline ... has persuasive/emotional advertising. & 0.609 & & & \\
\hline ... has informative advertising. & 0.567 & & & \\
\hline ... stands in contrast to the other stores. & 0.954 & & & \\
\hline I find ... very appealing. & 0.923 & & & \\
\hline I will recommend ... to my relatives and friends. & 0.878 & \multirow{5}{*}{$\begin{array}{c}\text { Store Patronage } \\
{[111,112]}\end{array}$} & \multirow{5}{*}{1.81} & \multirow{2}{*}{4.55} \\
\hline I feel very attached to.. & 0.842 & & & \\
\hline My next purchase will likely be from ... & 0.804 & & & \\
\hline I will often shop at ... in the future. & 0.785 & & & \\
\hline$\ldots$ has fair prices. & 0.782 & & & \multirow{5}{*}{4.40} \\
\hline ... maintains attractive prices for a long time. & 0.773 & \multirow{4}{*}{$\begin{array}{c}\text { Store prices } \\
{[110,113]}\end{array}$} & \multirow{4}{*}{1.72} & \\
\hline ... has an affordable price level. & 0.605 & & & \\
\hline ... provides a good quality-price ratio. & 0.555 & & & \\
\hline ... provides personalized service. & 0.820 & & & \\
\hline$\ldots$ has friendly employees, eager to help. & 0.770 & \multirow{5}{*}{$\begin{array}{c}\text { Store Personnel } \\
{[108,114]}\end{array}$} & \multirow{5}{*}{1.43} & \multirow{3}{*}{3.65} \\
\hline has well-trained and highly qualified employees. & 0.757 & & & \\
\hline ... provides good customer service. & 0.734 & & & \\
\hline ... carries new merchandise. & 0.737 & & & \multirow{6}{*}{2.97} \\
\hline ... carries innovative merchandise. & 0.701 & & & \\
\hline ... sells merchandise important to me. & 0.691 & \multirow{4}{*}{$\begin{array}{c}\text { Assortment } \\
\text { [108] }\end{array}$} & \multirow{4}{*}{1.15} & \\
\hline ... carries a good merchandise offer. & 0.569 & & & \\
\hline ... carries a good assortment of own brands. & 0.547 & & & \\
\hline Clothes are always available in ... & 0.533 & & & \\
\hline
\end{tabular}

Notes: EV: Eigenvariance; \% of var: percentage of variance; Factors in the order of their extraction. Extraction Method: Principal Axis Factoring. Rotation Method: Oblimin with Kaiser Normalization; Rotation converged in 12 iterations. 


\section{Results and Discussions}

The research model, shown in Figure 1, was estimated for Millennials $(\mathrm{Y})$ and Xers with structural equations modelling (AMOS) by using multigroup, see Table 3. All fit indices exceed the minimum thresholds levels (GFI/AGFI/NFI/CFI/TLI > 0.8; RMSEA/SRMR $\leq 0.08)$ recommended [104,105].

Table 3. Standardized estimates for enhancing apparel store patronage (ASP).

\begin{tabular}{|c|c|c|c|c|c|c|}
\hline Influences & X: 278 & Y: 402 & $x^{2}$ & df & $\chi^{2} / \mathrm{df}$ & AGFI \\
\hline Sustainability $\rightarrow$ ASP & $0.095^{\mathrm{n} . \mathrm{s}}$ & $0.093 *$ & 5985.24 & 2825 & 2.119 & 0.853 \\
\hline Assortment $\rightarrow$ ASP & $0.198^{*}$ & $0.240 * * *$ & \multicolumn{2}{|c|}{ RMSEA ( $(\leq 0.08)$} & NFI & TLI \\
\hline Prices $\rightarrow$ ASP & 0.099 n.s & $0.101 *$ & \multicolumn{2}{|c|}{0.036} & 0.834 & 0.930 \\
\hline Atmospherics $\rightarrow$ ASP & $0.058^{\mathrm{n} . \mathrm{s}}$ & $0.008^{\text {n.s }}$ & \multicolumn{2}{|c|}{ SRMR $(\leq 0.08)$} & CFI & GFI \\
\hline Personnel $\rightarrow$ ASP & $0.186^{* *}$ & $0.166^{* * * *}$ & \multicolumn{2}{|c|}{0.0642} & 0.938 & 0.885 \\
\hline Communication $\rightarrow$ ASP & $0.349 * * * *$ & $0.224^{* * * *}$ & \multirow{2}{*}{\multicolumn{2}{|c|}{$\begin{array}{rl}* * * * & p<0.001 \\
* & p<0.1\end{array}$}} & $* * * p<0.01$ & $* * p<0.05$ \\
\hline Convenience $\rightarrow$ ASP & $0.019^{\text {n.s }}$ & $0.049^{\text {n.s }}$ & & & \multicolumn{2}{|c|}{ n.s.-insignificant } \\
\hline
\end{tabular}

Apparel stores' sustainable behaviour has a weak influence on Millennials' store patronage (ASP) $\left(0.093^{*}\right)$ and no influence on Xers. Millennials are much more concerned about adopting responsible behaviour towards the environment than previous generations [115]. Most of them are aware that their buying decisions have a major direct impact over the future of the Earth [92], preferring companies that define their actions in line with sustainable development [116]. Generation Xers' approach to sustainable development is superficial, being more of a 'trendy' statement [90], which explains this generation's lack of interest in sustainable measures adopted by apparel retailers. On the other hand, even when consumers are concerned about sustainable development, their interest does not always translate into behaviour [117] due to other factors that have a greater influence on purchasing behaviour [118]. According to these results, we partially accept hypothesis $\mathrm{H}_{1}$ for Millennials and reject it for Generation X.

Assortment influences apparel store patronage, although this influence is more significant for Millennials $\left(0.240^{* *}\right)$ and less for Xers $\left(0.198^{*}\right)$. For Millennials to be trendy is very important [119], and they usually choose first the product and then identify the retailer from which they can purchase it [20]. In comparison with younger generations, Generation $X$ is less influenced by fashion trends [120], as it does not use products to show off its social status or to identify itself with other people [121]. Therefore, we can accept hypothesis $\mathrm{H}_{2}$ for Generation $\mathrm{Y}$, and only partially accept it for Generation X.

Apparel store prices have a relatively weak influence on apparel store patronage by Millennials $(0.101 *)$, and no influence in the case of Generation X. While Millennials are way more concerned with the price of apparel items than the older generations [122], at the same time, they are willing to pay more for high-quality, comfortable and durable products [119]. Xers have a low price sensitivity [87] and they seek high-quality products, even if they are more expensive [89], preferring quality over quantity [27]. Therefore, we can partially accept hypothesis $\mathrm{H}_{3}$ for Generation $\mathrm{Y}$ and reject it for Generation X.

Atmospherics has no influence either on Generation $Y$ patronage behaviour, or on Generation $X$, as no relationship is significant. This may be explained by the fact that store atmospherics and design first influence the consumer perception of the quality of articles sold and services provided by the store personnel $[11,56,57]$ and only indirectly influence consumer decisions to revisit and recommend the apparel store. Therefore, we reject hypothesis $\mathrm{H}_{4}$ for Generation $\mathrm{Y}$ and for Generation X.

Store personnel exerts moderate influence on apparel store patronage for Millennials $\left(0.166^{* * * *}\right)$ and Generation X $\left(0.186^{* *}\right)$. For Millennials, basic assistance in stores is not enough; they like to receive help and information from style-savvy fashion consultants who can inspire them [122]. Although Generation X usually get information from online sources [85], they still prefer to shop in bricks and mortar stores where they can find professional and helpful employees [87]. Therefore, we accept hypothesis $\mathrm{H}_{5}$ for Generation $\mathrm{Y}$ and for Generation X. 
Advertising exhibits quite a strong and significant influence on both Millennials' and Xers' apparel store patronage behaviour $\left(0.224^{* * *}\right.$ and $\left.0.349^{* * * *}\right)$. The importance of advertising for Generation $\mathrm{Y}$ may be related to brand awareness, because they are very interested in distinct, highly famous brands $[13,98,99,121]$. Unlike the other generations, Xers like to be thoroughly informed before deciding what articles to buy and what retailers to visit in order to get the best offering [120], and retailers' advertising campaigns are very helpful. Therefore, we fully accept hypothesis $\mathrm{H}_{6}$ for Millennials and Xers.

Store convenience does not exert any influence on the store patronage behaviour of Millennials and Xers. This might be due the fact that buying clothes is characterized by a high level of purchase involvement $[20,123]$, so consumers are more willing to allocate time and money to finding the best shopping alternative. Therefore, we reject hypothesis $\mathrm{H}_{7}$ for Generation $\mathrm{Y}$ and for Generation $\mathrm{X}$.

\section{Conclusions}

The apparel store patronage behaviour of Xers is influenced by apparel store advertising, personnel and assortment. Xers like advertisements that contain detailed and clear-cut information, as well as the reasons why one should buy a brand or visit a retailer $[87,89,120]$. These aspects may explain why apparel store advertising has the strongest influence on Xers' patronage behaviour. On the other hand, excellent customer service, which improves their shopping experience, represents one of the main reasons why Xers revisit stores $[87,120]$. This is also confirmed by our findings. The less significant influence of the assortment can be explained by the fact that Xers choose their brands very carefully, preferring products that suit their needs and lifestyle and can express their personality $[13,87]$. According to our results, store prices, atmospherics, convenience and sustainable behaviour have no influence on apparel store patronage by Xers.

Millennials' apparel store patronage behaviour is mostly influenced by the store's assortment, advertising and personnel. The strong influence of the assortment can be explained by the fact that Millennials are very concerned with fashion [20] and the way they are perceived by their peers, and they use clothes as status symbols [122]. Moreover, conspicuous brands serve an important social function by providing young people with the opportunity to display their individualism and personal tastes through the goods they purchase and to impress their peers [97]. This may also explain the influence of advertising. Apparel store employees' attitude and professionalism foster return to and recommendation of the apparel store, because experience of a retailer is very important for Millennials [124], and their interaction with personnel can improve this experience [123]. Prices and sustainable behaviour have a less significant influence on Millennials' patronage behaviour. On the one hand, Millennials are concerned with apparel prices, but even those on low incomes are willing to pay large amounts of money for products perceived to be image boosters [91]. On the other hand, Millennials prefer companies that implement sustainable strategies [124], but do not necessarily patronize them. A possible explanation might be that although consumers are interested in sustainable development, their interest does not always materialize at behavioural level $[125,126]$, and the fact that it was evaluated at the same time as other store attributes that are known to influence store patronage. Apparel store atmospherics and convenience have no influence on patronage behaviour for Millennials. Based on all these results, we argue that there are similarities, but also differences in terms of retail attributes that influence Xers' and Millennials' apparel store patronage behaviour.

The theoretical contribution lies in enriching knowledge about consumer generations, especially by highlighting the factors that foster apparel store patronage of two generations, $X$ and $Y$. We have empirically demonstrated that there are relevant differences between Millennials and Xers in terms of patronage behaviour towards apparel retailers. Our findings could assist apparel retailers to better understand factors that might lead to patronage behaviour in order to develop better marketing strategies to attract and retain Millennials or Xers. As for the consumer segment composed of Xers, apparel retailers should concentrate their attention on the selling personnel, which should be more polite and capable of offering proper information requested by clients regarding the store, the merchandise 
and the sold items. Another differentiation element could be represented by the advertising messages, which should be more informative and able to convince clients to revisit apparel store. To determine patronage behaviour of generation $Y$, apparel retailers should pay a greater attention to the assortment which should be in line with the new fashion trends, advertising campaigns, as well as to focus on selling personnel which is able to enhance Millennials in store shopping experience. Adopting a sustainable behaviour could be another differentiation element which might lead to the attraction and binding of Millennials towards apparel stores.

Among the research limitations are the relatively unequal number of respondents within each generation, as well as the fact that almost $90 \%$ of the responses were obtained for international apparel retail chains. The research has focused on only two consumer generations, but further studies should take into consideration also the behaviour of Baby Boomers or Generation Z. Future research directions may also consider a comparative analysis which also includes Generation $Z$, a comparative analysis between retailers who implement and communicate sustainability strategies versus those who do not, or between international versus domestic apparel retailers. Besides taking into consideration the patronage behaviour, future studies should also rely on addressing and describing the store image, as a prerequisite for enhancing store patronage. Last but not least, the connection between generational oriented innovations and store patronage could be analysed.

Author Contributions: Conceptualization, D.-C.D. and R.B.; Methodology, D.-C.D.; Resources, R.B.; Data Curation, D.-C.D. and R.B.; Writing-Original Draft Preparation, D.-C.D. and R.B.; Writing-Review \& Editing, D.-C.D.; Funding Acquisition, D.-C.D.

Funding: This work was supported by a grant of the Romanian National Authority for Scientific Research and Innovation, CNCS-UEFISCDI, project number PN-II-RU-TE-2014-4-0312 and Babes-Bolyai University Star UBB Advanced Fellowships, Project 33PFE/2018 "Strategic Infrastructure at the Babes-Bolyai University for Developing new and emergent Technologies 2018-2020".

Conflicts of Interest: The authors declare no conflicts of interest.

\section{References}

1. Zadek, S. The Path to Corporate Responsibility. Harv. Bus. Rev. 2004, 82, 125-132.

2. Hethorn, J.; Ulasewicz, C. Sustainable Fashion: Why Now; Fairchild Books: New York, NY, USA, 2008.

3. Gupta, M.; Hodges, N. Corporate Social Responsibility in the Apparel Industry: An Exploration of Indian Consumers' Perceptions and Expectations. J. Fash. Mark. Manag. 2012, 16, 216-233. [CrossRef]

4. Dabija, D.C.; Pop, N.A.; Postelnicu, C. Ethics of the Garment Retail within the Context of Globalization and Sustainable Development. Ind. Text. 2016, 67, 270-279.

5. Dabija, D.C.; Pop, N.A.; Szentesi, S. A Customer-Oriented Perspective on Retail Brand Equity in the Fashion Industry. Ind. Text. 2014, 65, 37-46.

6. Baron, D.P.; Agus-Harjoto, M.; Jo, H. The Economics and Politics of Corporate Social Performance. Bus. Politics 2011, 13, 1-46. [CrossRef]

7. Moisander, J.; Personen, S. Narratives of Sustainable Ways of Living: Constructing the Self and Others as a Green Consumer. Manag. Decis. 2002, 40, 329-342. [CrossRef]

8. Ferrell, O.C.; Rogers, M.M.; Ferrell, L.; Sawayda, J. A Framework for Understanding Ethical Supply Chain Decision Making. J. Mark. Channels 2013, 20, 260-287. [CrossRef]

9. Diddi, S.; Niehm, L.S. Corporate Social Responsibility in the Retail Apparel Context: Exploring Consumers' Personal and Normative Influences on Patronage Intentions. J. Mark. Channels 2016, 23, 60-76. [CrossRef]

10. Seock, Y.K.; Lin, C. Cultural Influence on Loyalty Tendency and Evaluation of Retail Store Attributes: An analysis of Taiwanese and American consumers. Int. J. Retail Distrib. Manag. 2011, 39, 94-113. [CrossRef]

11. Baker, J.; Parasuraman, A.; Grewal, D.; Voss, G.B. The Influence of Multiple Store Environment Cues on Perceived Merchandise Value and Patronage Intentions. J. Mark. 2002, 66, 120-141. [CrossRef]

12. Pan, Y.; Zinkhan, G.M. Determinants of Retail Patronage: A Meta-Analytical Perspective. J. Retail. 2006, 82, 229-243. [CrossRef]

13. Moore, M.; Carpenter, J.M. Intergenerational Perceptions of Market Cues among US Apparel Consumers. J. Fash. Mark. Manag. Int. J. 2008, 12, 323-337. [CrossRef] 
14. Chang, H.J.; Cho, H.J.; Turner, T.; Gupta, M.; Watchravesringkan, K. Effects of Store Attributes on Retail Patronage Behaviours: Evidence from Active Wear Specialty Stores. J. Fash. Mark. Manag. 2015, 19, 136-153. [CrossRef]

15. Weise, A.; Kellner, J.; Lietke, B.; Toporowski, W.; Zielke, S. Sustainability in Retailing: A Summative Content Analysis. Int. J. Retail Distrib. 2012, 40, 318-335. [CrossRef]

16. Ritch, E.L. Consumers Interpreting Sustainability: Moving beyond Food to Fashion. Int. J. Retail Distrib. Manag. 2015, 43, 1162-1181. [CrossRef]

17. Strauss, W.; Howe, N. Generations. The History of America's Future, 1584 to 2069, 1st ed.; Harper Perennial: New York, NY, USA, 1991.

18. Schewe, C.; Meredith, G. Segmenting Global Markets by Generational Cohorts: Determining Motivations by Age. J. Consum. Behav. 2004, 4, 51-63. [CrossRef]

19. Howe, N.; Strauss, W. The Next 20 Years: How Customer and Workforce Attitudes Will Evolve. Harv. Bus. Rev. 2007, 85, 41-52. [PubMed]

20. Parment, A. Generation Y vs. Baby Boomers: Shopping Behavior, Buyer Involvement and Implications for Retailers. J. Retail. Consum. Serv. 2013, 20, 189-199. [CrossRef]

21. Lazarevic, V. Encouraging Brand Loyalty in Fickle Generation Y Consumers. Young Consum. 2012, 13, 45-61. [CrossRef]

22. Dabija, D.C.; Băbuţ, R.; Dinu, V.; Lugojan, M. Cross-Generational Analysis of Information Searching based on Social Media in Romania. Transform. Bus. Econ. 2017, 16, 248-270.

23. Eastman, J.K.; Iyer, R.; Liao-Troth, S.; Williams, D.F.; Griffin, M. The Role of Involvement on Millennials' Mobile Technology Behaviors: The Moderating Impact of Status Consumption, Innovation, and Opinion Leadership. J. Mark. Theory Pract. 2014, 22, 455-470. [CrossRef]

24. Vatamanescu, E.M.; Nistoreanu, B.G.; Mitan, A. Competition and Consumer Behaviour in the Context of the Digital Economy. Amfiteatru Econ. 2017, 19, 354-366.

25. Oláh, J.; Kitukutha, N.; Haddad, H.; Pakurár, M.; Máté, D.; Popp, J. Achieving Sustainable E-Commerce in Environmental, Social and Economic Dimensions by Taking Possible Trade-Offs. Sustainability 2019, 11, 89. [CrossRef]

26. Barber, N.; Taylor, D.C.; Strick, S. Selective marketing to environmentally concerned wine consumers: A case for location, gender and age. J. Consum. Mark. 2010, 27, 64-75. [CrossRef]

27. Euromonitor. The World's Gen Xers. 2009. Available online: www.euromonitor.com/the-worlds-gen-xerslatchkey-kids-29-44s-come-into-their-own/report (accessed on 20 June 2017).

28. Gilboa, S.; Vilnai-Yavetz, I. Four Generations of Mall Visitors in Israel: A Study of Mall Activities, Visiting Patterns, and Products Purchased. J. Retail. Consum. Serv. 2010, 17, 501-511. [CrossRef]

29. Gurău, C. A Life-Stage Analysis of Consumer Loyalty Profile: Comparing Generation X and Millennial Consumers. J. Consum. Mark. 2012, 29, 103-113. [CrossRef]

30. Lissitsa, S.; Kol, O. Generation X vs. Generation Y: A decade of online shopping. J. Retail. Consum. Serv. 2016, 31, 304-312. [CrossRef]

31. Dabija, D.C.; Bejan, B.M.; Tipi, N. Generation X versus Y communication behaviour on social media when purchasing food versus touristic services. Ekon. A Manag. 2018, 21, 191-205. [CrossRef]

32. Zeithaml, V.A.; Berry, L.L.; Parasuraman, A. The Behavioural Consequences of Service Quality. J. Mark. 1996, 60, 31-46. [CrossRef]

33. Zeithaml, V.A. Consumer Perceptions of Price, Quality and Value: A Means-End Model and Synthesis of Evidence. J. Mark. 1988, 52, 2-22. [CrossRef]

34. Swoboda, B.; Pop, N.A.; Dabija, D.C. Vertical Alliances between Retail and Manufacturer Companies in the Fashion Industry. Amfiteatru Econ. 2010, 12, 634-649.

35. Yang, S.; Song, Y.; Tong, S. Sustainable Retailing in the Fashion Industry: A Systematic Literature Review. Sustainability 2017, 9, 1266. [CrossRef]

36. Epuran, G.; Brătucu, G.; Bărbulescu, O.; Neacşu, N.A.; Madar, A. Food Safety and Sustainability: An Exploratory Approach at the Level of the Romanian Wine Production Companies. Amfiteatru Econ. 2018, 20, 151-167. [CrossRef]

37. Musová, Z.; Musa, H.; Ludhova, L. Environmentally Responsible Purchasing in Slovakia. Econ. Sociol. 2018, 11, 289-305. [CrossRef] 
38. Thorisdottir, T.S.; Johannsdottir, L. Sustainability within Fashion Business Models: A Systematic Literature Review. Sustainability 2019, 11, 2233. [CrossRef]

39. Bocken, N.M.P.; Short, S.W.; Rana, P.; Evans, S. A Literature and Practice Review to Develop Sustainable Business Model Archetypes. J. Clean. Prod. 2014, 65, 42-56. [CrossRef]

40. Brehmer, M.; Podoynitsyna, K.; Langerak, F. Sustainable business models as boundary-spanning systems of value transfers. J. Clean. Prod. 2018, 172, 4514-4531. [CrossRef]

41. Kanchanapibul, M.; Lacka, E.; Wang, X.; Chan, H.K. An Empirical Investigation of Green Purchase Behaviour among the Young Generation. J. Clean. Prod. 2014, 66, 528-536. [CrossRef]

42. Woosnam, K.M.; Strzelecka, M.; Nisbett, G.S.; Keith, S.J. Examining Millennials' Global Citizenship Attitudes and Behavioral Intentions to Engage in Environmental Volunteering. Sustainability 2019, 11, 2324. [CrossRef]

43. Bruntland Report. WCED—World Commission on Environment and Development. In Our Common Future; Oxford University Press: Oxford, UK, 1987.

44. Elkington, J. Towards the Sustainable Corporation: Win-Win-Win Business Strategies for Sustainable Development. Calif. Manag. Rev. 1994, 36, 90-100. [CrossRef]

45. Dabija, D.C.; Băbut, R. An Approach to Sustainable Development from Tourist's Perspective. Empirical Evidence in Romania. Amfiteatru Econ. 2013, 15, 617-633.

46. Shen, B.; Li, Q.; Dong, C.; Perry, P. Sustainability Issues in Textile and Apparel Supply Chains. Sustainability 2017, 9, 1592. [CrossRef]

47. Maloni, M.J.; Brown, M.E. Corporate Social Responsibility in the Supply Chain: An Application in the Food Industry. J. Bus. Ethics 2006, 68, 35-52. [CrossRef]

48. Langenwater, G.A. Planet First. Ind. Manag. 2009, 51, 10-13.

49. Gazzola, P.; Vătămănescu, E.M.; Andrei, A.G.; Marrapodi, C. Users' motivations to participate in the sharing economy: Moving from profits toward sustainable development. Corp. Soc. Responsab. Environ. Manag. 2019, 26, 741-751. [CrossRef]

50. Dawkins, J.; Lewis, S. CSR in Stakeholder Expectations and their Implication for Company Strategy. J. Bus. Ethics 2003, 44, 185-193. [CrossRef]

51. Bhattacharya, C.B.; Sen, S. Doing Better at Doing Good: When, Why, and How Consumers Respond to Corporate Social Initiatives. Calif. Manag. Rev. 2004, 47, 9-24. [CrossRef]

52. Bezençon, V.; Etemad-Sajadi, R. The Effect of a Sustainable Label Portfolio on Consumer Perception of Ethicality and Retail Patronage. Int. J. Retail Distrib. Manag. 2015, 43, 314-328. [CrossRef]

53. Morrison, G.P. Driving Successful Shopping Occasions through Deeper Insights. Eur. Retail Dig. 2006, 49, 65-75.

54. Newman, A.J.; Patel, D. The Marketing Directions of Two Fashion Retailers. Eur. J. Mark. 2004, 38, 770-789. [CrossRef]

55. Sullivan, P.; Savitt, R.; Zheng, Y.; Cui, Y. Rural Shoppers: Who Gets their Apparel Dollars? J. Fash. Mark. Manag. Int. J. 2002, 6, 363-380. [CrossRef]

56. Thang, D.C.L.; Tan, B.L.B. Linking Consumer Perception to Preference of Retail Stores: An Empirical Assessment of the Multi-attributes of Store Patronage. J. Retail. Consum. Serv. 2003, 10, 193-200. [CrossRef]

57. Birtwistle, G.; Clarke, I.; Freathy, P. Store Patronage in the UK Fashion Sector: Consumer versus Retailer Perceptions. Int. Rev. Retail Distrib. Consum. Res. 1999, 9, 1-16. [CrossRef]

58. Birtwistle, G.; Shearer, L. Consumer Perception of Five UK Fashion Retailers. J. Fash. Mark. Manag. Int. J. 2001, 5, 9-18. [CrossRef]

59. Kwon, W.S.; Lennon, S.J. Assessing College Women's Associations of American Specialty Apparel Brands. J. Fash. Mark. Manag. Int. J. 2011, 15, 242-256. [CrossRef]

60. Bradley, F. International Marketing Strategy, 5th ed.; Pearson Education: Toronto, ON, Canada, 2004.

61. Van Noordwyk, H.J. The Development of a Scale for the Measurement of the Perceived Importance of the Dimensions of Apparel Store Patronage. Stellenbosch University, 2008. Available online: http: //scholar.sun.ac.za/handle/10019.1/1269 (accessed on 15 March 2017).

62. Arnold, S.J.; Oum, T.H.; Tigert, D.J. Determinant Attributes in Retail Patronage: Seasonal, Temporal, Regional, and International Comparisons. J. Mark. Res. 1983, 20, 149-157. [CrossRef]

63. Hampl, N.; Loock, M. Sustainable Development in Retailing: What is the Impact on Store Choice? Bus. Strategy Environ. 2013, 22, 202-216. [CrossRef] 
64. Moore, M.; Carpenter, J. The Effect of Price as a Marketplace Cue on Retail Patronage. J. Prod. Brand Manag. 2006, 15, 265-271. [CrossRef]

65. Swoboda, B.; Berg, B.; Dabija, D.C. International Transfer and Perception of Retail Formats: A comparison Study in Germany and Romania. Int. Mark. Rev. 2014, 31, 155-180. [CrossRef]

66. Hartman, K.B.; Spiro, R.L. Recapturing Store Patronage in Customer-based Store Equity: A Construct Conceptualization. J. Bus. Res. 2005, 58, 1112-1120. [CrossRef]

67. Broekemier, G.; Marquardt, R.; Gentry, J.W. An Exploration of Happy/Sad and Liked/Disliked Music Effects on Shopping Intentions in a Woman's Clothing Store Service Setting. J. Serv. Mark. 2008, 22, 59-67. [CrossRef]

68. Anselmsson, J. Sources of Customer Satisfaction with Shopping Malls: A Comparative Study of Different Customer Segments. Int. Rev. Retail Distrib. Consum. Res. 2006, 16, 115-138. [CrossRef]

69. Harris, K.; Baron, S.; Parker, C. Understanding the Consumer Experience: It's 'Good to Talk'. J. Mark. Manag. 2000, 16, 111-127. [CrossRef]

70. Mitchell, C. Selling the Brand Inside. Harv. Bus. Rev. 2002, 80, 99-105. [PubMed]

71. Miranda, M.J.; Konya, L.; Havrila, I. Shoppers' Satisfaction Levels Are not the only Key to Store Loyalty. Mark. Intell. Plan. 2005, 23, 220-232. [CrossRef]

72. Grewal, D.; Baker, J.; Levy, M.; Voss, B.V. The Effects of Wait Expectations and Store Atmosphere Evaluations on Patronage Intentions in Service-intensive Retail Stores. J. Retail. 2003, 79, 259-268. [CrossRef]

73. Moschis, G.P.; Ferguson, J.L.; Zhu, M. Mature Consumers' Selection of Apparel and Footwear Brands and Department Stores. Int. J. Retail Distrib. Manag. 2011, 39, 785-801. [CrossRef]

74. Hansen, R.; Deutscher, T. An Empirical Investigation of Attribute Importance in Retail Store Selection. J. Retail. 1977, 53, 59-72.

75. Dabija, D.C.; Băbuț, R. Enhancing Consumers' Satisfaction and Loyalty of Retailers in Romania through Store Ambiance and Communication. Procedia Econ. Financ. 2014, 15, 371-382. [CrossRef]

76. Paulins, V.A.; Geistfeld, L.V. The Effect of Consumer Perceptions of Store Attributes on Apparel Store Preference. J. Fash. Mark. Manag. 2003, 7, 371-385. [CrossRef]

77. Dabija, D.C.; Băbuţ, R. Empirical Study on the Impact of Service, Communication and Corporate Social Responsability on the Image of Romanian Retail Brands. Procedia Soc. Behav. Sci. 2014, 109, 906-912. [CrossRef]

78. Hsu, M.K.; Huang, Y.; Swanson, S. Grocery Store Patronage, Travel Distance, Satisfaction and Behavioral Intentions: Evidence from a Midwest College Town. Int. J. Retail Distrib. Manag. 2010, 38, 115-132. [CrossRef]

79. Obucina, V. Romania Shows Fast Economic Growth after 10 Years in the EU. Available online: https://financialobserver.eu/cse-and-cis/romania/romania-shows-fast-economic-growth-after-10yearsin-eu (accessed on 12 November 2018).

80. Dabija, D.C.; Abrudan, I.N. Retailing in Romania: From Statist to Nearly Capitalist. Eur. Retail Res. 2015, 27, 55-92. [CrossRef]

81. Euromonitor. Apparel and Footwear in Romania. 2016. Available online: www.euromonitor.com/appareland-footwear-in-romania/report (accessed on 24 June 2017).

82. Rosca, C. Business Magazine. 2016. Available online: www.businessmagazin.ro/analize/comert/diavolii-seimbraca-de-la-prada-romanii-prefera-online-ul-15106910 (accessed on 8 April 2018).

83. Euromonitor. Apparel and Footwear Specialist Retailers in Romania. 2017. Available online: www. euromonitor.com/apparel-and-footwear-specialist-retailers-in-romania/report (accessed on 24 June 2017).

84. Doster, L. Millennial Teens Design and Redesign Themselves in Online Social Networks. J. Consum. Behav. 2013, 12, 267-279. [CrossRef]

85. Lan, S. An Importance-Performance Analysis of Multigenerational Preferences in Guestroom Technology; University of Nevada: Las Vegas, NV, USA, 2014; p. 2620.

86. Hernaus, T.; Pološki-Vokic, N. Work Design for Different Generational Cohorts. J. Organ. Chang. Manag. 2014, 27, 615-641. [CrossRef]

87. Williams, K.C.; Page, R.A. Marketing to the Generations. J. Behav. Stud. Bus. 2011, 3, 1-17.

88. Acar, A.B. Do Intrinsic and Extrinsic Motivation Factors Differ for Generation X and Generation Y? Int. J. Bus. Soc. Sci. 2014, 5, 12-20.

89. Peralta, E. Generation X: The Small but Financially Powerful Generation. 2015. Available online: www. centro.net/blog/generation-x-the-small-but-mighty-generation (accessed on 12 May 2018). 
90. Taylor, P.; Gao, G. Generation X: America's Neglected 'Middle Child'. PewResearch Center, 2014. Available online: www.pewresearch.org/fact-tank/2014/06/05/generation-X-americas-neglected-middle-child (accessed on 21 July 2016).

91. Euromonitor. Eco Worriers: Global Green Behaviour and Market Impact. 2015. Available online: www. euromonitor.com/eco-worriers-global-green-behaviour-and-market-impact/report (accessed on 5 May 2016).

92. Taken-Smith, K.; Brower, T.R. Longitudinal Study of Green Marketing Strategies that Influence Millennials. J. Strateg. Mark. 2012, 20, 535-551. [CrossRef]

93. Young, E. How Millennials Get News: Inside the Habits of America's First Digital Generation; NORC Centre for Public Affairs Research \& American Press Institute: Chicago, IL, USA, 2015.

94. Duh, H.; Struwig, M. Justification of Generational Cohort Segmentation in South Africa. Int. J. Emerg. Mark. 2015, 10, 89-101. [CrossRef]

95. Martin, C.A.; Turley, L. Malls and Consumption Motivation: An Exploratory Examination of Older Generation Y Consumers. Int. J. Retail Distrib. Manag. 2004, 32, 464-475. [CrossRef]

96. Kinley, T.R.; Josia, B.M.; Lockett, F. Shopping Behavior and the Involvement Construct. J. Fash. Mark. Manag. Int. J. 2010, 14, 562-575. [CrossRef]

97. Fernandez, P.R.; Lean, M.L. Chasing Gen Y: Unlocking the Reasons for Buying Branded Clothes. In Proceedings of the Conference on Economics, Business Management and Marketing, Singapore, Singapore, 9-11 October 2009; pp. 73-77.

98. Noble, S.M.; Haytko, D.L.; Phillips, J. What Drives College-age Generation Y Consumers? J. Bus. Res. 2009, 62, 617-628. [CrossRef]

99. Euromonitor. Millennials Impact of their Behaviour on Global Consumer Markets. 2015. Available online: www.euromonitor.com/millennials-impact-of-their-behaviour-on-global-consumer-markets/report (accessed on 7 June 2016).

100. Bonadonna, A.; Giachino, C.; Truant, E. Sustainability and Mountain Tourism: The Millennial's Perspective. Sustainability 2017, 9, 1219. [CrossRef]

101. Statistical Yearbook. 2014. Available online: www.insse.ro/cms/files/publicatii/Romania_in_Cifre_2014.pdf (accessed on 15 February 2016).

102. Churchill, G.A. Marketing Research: Methodological Foundation, 5th ed.; The Dryden Press: New York, NY, USA, 1991.

103. Walsh, G.; Beatty, S.E. Customer Based Corporate Reputation of a Service Firm: Scale Development and Validation. J. Acad. Mark. Sci. 2007, 35, 127-143. [CrossRef]

104. Forza, C.; Filippini, R. TQM Impact on Quality Conformance and Customer Satisfaction: A Causal Model. Int. J. Prod. Econ. 1998, 55, 1-20. [CrossRef]

105. Ju, T.L.; Lin, B.; Lin, C.; Kuo, H.J. TQM Critical Factors and KM Value Chain Activities. Total Qual. Manag. 2006, 17, 373-393. [CrossRef]

106. Brown, T.; Dacin, P.A. The Company and the Product: Corporate Associations and Consumer Product Responses. J. Mark. 1997, 61, 68-84. [CrossRef]

107. Sen, S.; Bhattacharya, C.B. Does Doing Good Always Lead to Doing Better? Consumer Reactions to Corporate Social Responsibility. J. Mark. Res. 2001, 38, 225-243. [CrossRef]

108. Chowdhury, J.; Reardon, J.; Srivastava, R. Alternative Modes of Measuring Store Patronage: An Empirical Assessment of Structured versus Unstructured Measures. J. Mark. Theory Pract. 1998, 6, 72-86. [CrossRef]

109. Oppewal, H.; Timmermans, H. Retailer Self-Perceived Store Patronage and Competitive Position. Int. Rev. Retail Distrib. Consum. Res. 1997, 7, 41-59. [CrossRef]

110. Yoo, B.; Donthu, N.; Lee, S. An Examination of Selected Marketing Mix Elements and Brand Equity. J. Acad. Mark. Sci. 2000, 28, 195-211. [CrossRef]

111. Chaudhuri, A.; Holbrook, M.B. The Chain of Effects from Brand Trust and Brand Affect to Brand Performance: The Role of Brand Loyalty. J. Mark. 2001, 65, 81-93. [CrossRef]

112. Harris, L.C.; Goode, M.M. The Four Levels of Loyalty and the Pivotal Role of Trust: A Study of Online Service Dynamics. J. Retail. 2004, 80, 139-158. [CrossRef]

113. Grewal, D.; Krishnan, R.; Baker, J.; Borin, N. The Effect of Store Name, Brand Name and Price Discounts on Consumers' Evaluations and Purchase Intentions. J. Retail. 1998, 74, 331-352. [CrossRef]

114. Sirdeshmukh, D.; Singh, J.; Sabol, B. Consumer Trust, Value, and Loyalty in Relational Exchanges. J. Mark. 2002, 66, 15-37. [CrossRef] 
115. Royne, M.B.; Levy, M.; Martinez, J. The Public Health Implications of Consumers' Environmental Concern and Their Willingness to Pay for an Eco-Friendly Product. J. Consum. Aff. 2011, 45, 329-343. [CrossRef]

116. Laroche, M.; Bergeron, J.; Barbaro-Forleo, G. Targeting Consumers who are Willing to Pay More for Environmentally Friendly Products. J. Consum. Mark. 2001, 18, 503-520. [CrossRef]

117. Bonini, S.; Oppenheim, J. Cultivating the Green Consumer. Stanf. Soc. Innov. Rev. 2008, 6, 56-61.

118. Carrigan, M.; Attalla, A. The Myth of the Ethical Consumer-Do Ethics Matter in Purchase Behavior? J. Consum. Mark. 2001, 18, 560-578. [CrossRef]

119. Euromonitor. Personal Appearances: Global Consumer Survey Results on Apparel, Beauty and Grooming. 2014. Available online: www.euromonitor.com/personal-appearances-global-consumer-survey-results-onapparel-beauty-and-grooming/report (accessed on 24 June 2017).

120. Williams, E. Generation X Consumer Behavior. 2017. Available online: http://yourbusiness.azcentral.com/ generation-X-consumer-behavior-9585.html (accessed on 20 June 2017).

121. Ordun, G. Millennial (Gen Y) Consumer Behavior, Their Shopping Preferences and Perceptual Maps Associated with Brand Loyalty. Can. Soc. Sci. 2015, 11, 40-55. [CrossRef]

122. Fromm, J.; Garton, C. Marketing to Millennials: Reach the Largest and Most Influential Generation of Consumer Ever; AMACOM. Barkley, Inc.: Kansas City, MO, USA, 2013.

123. Vahie, A.; Paswan, A. Private Label Brand Patronage: Its relationship with Store Patronage and National Brand. Int. J. Retail Distrib. Manag. 2006, 34, 67-84. [CrossRef]

124. Parment, A. Global Data on Society, Consumption and Identity. In Marketing to the 90s Generation; Palgrave MacMillan: Basingstoke, UK, 2014.

125. Levi Jakšić, M.; Rakićević, J.; Jovanović, M. Sustainable Technology and Business Innovation Framework-A Comprehensive Approach. Amfiteatru Econ. 2018, 20, 418-436. [CrossRef]

126. Bray, J.; Johns, N.; Kilburn, D. An Exploratory Study into the Actors Impeding Ethical Consumption. J. Bus. Ethics 2011, 98, 597-608. [CrossRef]

(C) 2019 by the authors. Licensee MDPI, Basel, Switzerland. This article is an open access article distributed under the terms and conditions of the Creative Commons Attribution (CC BY) license (http://creativecommons.org/licenses/by/4.0/). 